\title{
Cytotoxic activity of the twigs of Cinnamomum cassia through the suppression of cell proliferation and the induction of apoptosis in human colorectal cancer cells
}

Gwang Hun Park ${ }^{1 \dagger}$, Hun Min Song ${ }^{2 \dagger}$, Su Bin Park ${ }^{2 \dagger}$, Ho-Jun Son ${ }^{1}$, Yurry Um¹ ${ }^{1}$ Hyun-Seok Kim ${ }^{3}$ and Jin Boo Jeong ${ }^{2,4^{*}}$

\begin{abstract}
Background: Because twigs of Cinnamomum cassia (TC) have been reported to exert anti-cancer activity, the mechanistic study for TC's anti-cancer activity is required. Thus, we elucidated the potential molecular mechanism of TC's anti-proliferative effect and the induction of apoptosis in human colorectal cancer cells.

Methods: How water extracts form TC (TC-HW) was used in this study. Anti-cell proliferative effect of TC-HW was evaluated by MTT assay. The change of protein or mRNA level by TC-HW was evaluated by Western blot and RT-RCR, respectively. The promoter construct for ATF3, NF-KB, TOP-FLASH or FOP-FLASH was used for the investigation of the transcriptional activity for ATF3, NF-kB or Wnt. siRNA for ATF3 or p65 was used for the knockdown of ATF3 and p65.

Results: TC-HW reduced the cell viability in human colorectal cancer cells. TC-HW decreased cyclin D1 protein level through cyclin D1 degradation via GSK33-dependent threonine-286 (T286) phosphorylation of cyclin D1, indicating that cyclin D1 degradation may contribute to TC-HW-mediated decrease of cyclin D1 protein level. TC-HW downregulated the expression of cyclin D1 mRNA level and inhibited Wnt activation through the downregulation of $\beta$-catenin and TCF4 expression, indicating that inhibition of cyclin D1 transcription may also result in TC-HW-mediated decrease of cyclin D1 protein level. In addition, TC-HW was observed to induce apoptosis through ROS-dependent DNA damage. TC-HWinduced ROS increased NF-KB and ATF3 activation, and inhibition of NF-KB and ATF3 activation attenuated TC-HWmediated apoptosis.
\end{abstract}

Conclusions: Our results suggest that TC-HW may suppress cell proliferation through the downregulation of cyclin D1 via proteasomal degradation and transcriptional inhibition, and may induce apoptosis through ROSdependent NF-KB and ATF3 activation. These effects of TC-HW may contribute to the reduction of cell viability in human colorectal cancer cells. From these findings, TC-HW has potential to be a candidate for the development of chemoprevention or therapeutic agents for human colorectal cancer.

Keywords: Anticancer, ATF3, Cinnamomum cassia, Cyclin D1;.Human colorectal cancer, NF-KB, ROS, Twigs of Cinnamomum cassia

\footnotetext{
* Correspondence: jjb0403@anu.ac.kr

${ }^{\dagger}$ Equal contributors

${ }^{2}$ Department of Medicinal Plant Resources, Andong National University,

Andong 36729, Republic of Korea

${ }^{4}$ Insititute of Agricultural Science and Technology, Andong National

University, Andong 36729, Republic of Korea

Full list of author information is available at the end of the article
} 


\section{Background}

Among a verity of cancers, human colorectal cancer (CRC) has been regarded as an one of the most common types of cancer and a major cause of cancer-related mortality [1]. Although the improvements of CRC treatment have been achieved, the death rate by CRC still remains high because of the advanced, metastatic or recurrent CRC [2-4]. Therefore, the development of the novel treatment for CRC has been required.

Natural products have been long regarded as one of the potential materials for developing the anti-cancer agents. Traditional Chinese medicine (TCM) has been used for the treatment of human diseases $[5,6]$. Cinnamomum cassia $(C$. cassia) as an aromatic plant from Lauraceae family found in southern China, Vietnam, Myanmar and Laos has been widely used for treating blood circulation disturbances, dyspepsia, allergic disease, gastritis, diabetes, and other inflammatory diseases [7]. Among the bark and twigs of $C$. cassia, the bark of $C$. cassia has been applied to treating cold intolerance, weakness, soreness and coldness of lower back and knees [8]. The bark of C. cassia has been reported to have neuro-protective effect, antiinflammatory effect and anti-cancer activity [9-11]. The twigs of $C$. cassia have been widely treated for menstrual pain, fever, hypertension, diabetes and cancer [12-14]. According to the many literatures, twigs of C. cassia (TC) exert the pharmacological activities such as anti-allergy, insecticidal, antimicrobial, antiulcer, anti-inflammatory, vasodilatory, immune-suppressive, and neuronal death prevention, tyrosinase inhibition and anticancer, antioxidant and free radical scavenging, as well as antidiabetic and aldose reductase inhibition activities [15]. In anticancer activity, TC suppressed the abnormal proliferation in JB6 P+ cells through c-Fos degradation. However, additional molecular mechanism for the anticancer activity of TC still remains to be elucidated. In this study, we elucidated anti-cancer activity and potential molecular mechanism of TC against human colorectal cancer cells. We here reported the additional mechanism of hot-water extracts from the twigs of Cinnamomum cassia (TC-HW) for anti-cancer activity. TC-HW suppressed the proliferation of human colorectal cancer cells through GSK3 $\beta$ dependent cyclin D1 degradation and induced ROSdependent apoptosis in human colorectal cancer cells.

\section{Methods}

\section{Materials}

Dulbecco's Modified Eagle medium (DMEM)/F-12 1:1 Modified medium (DMEM/F-12) for the cell culture was purchased from Lonza (Walkersville, MD, USA). LiCl, MG132 and 3-(4,5-dimethylthizaol-2-yl)-2,5-diphenyl tetrazolium bromide (MTT) and N-acetyl-L-cysteine (NAC) were purchased from Sigma Aldrich (St. Louis, MO, USA). Antibodies against cyclin D1, phospho-cyclin D1 (Thr286),
HA-tag, $\beta$-catenin, TCF4, cleaved PARP, phospho-H2AX, IkB- $\alpha$, p 65 and $\beta$-actin were purchased from Cell Signaling (Bervely, MA, USA). Antibody for activating transcription factor (ATF3) was purchased from Santa Cruz Inc. (Santa Cruz, CA, USA). All chemicals were purchased from Fisher Scientific, unless otherwise specified.

\section{Sample preparation}

The twigs of Cinnamomum cassia (TC) (voucher number: Jeong1001(AHN)) was purchased from Humanherb, Korea and formally identified by Jin Suk Koo as the professor of Andong National University, Korea. Twenty gram of TC was extracted with $300 \mathrm{ml}$ of $\mathrm{DH}_{2} \mathrm{O}$ with boiling at $100{ }^{\circ} \mathrm{C}$ for $1 \mathrm{~h}$. After $1 \mathrm{~h}$, the hot water extracts were filtered and then freeze-dried. The hot water extracts from TC (TC-HW) was kept in a refrigerator until use.

\section{Cell culture and treatment}

Human colorectal cancer cell lines such as HCT116, SW480, LoVo and HT-29 were purchased from Korean Cell Line Bank (Seoul, Korea) and grown in DMEM/F12 supplemented with $10 \%$ fatal bovine serum (FBS), $100 \mathrm{U} / \mathrm{ml}$ penicillin and $100 \mu \mathrm{g} / \mathrm{ml}$ streptomycin. The cells were maintained at $37{ }^{\circ} \mathrm{C}$ under a humidified atmosphere of $5 \% \mathrm{CO}_{2}$. TC-HW was dissolved in dimethyl sulfoxide (DMSO) and treated to cells. DMSO was used as a vehicle and the final DMSO concentration did not exceed $0.1 \%(v / v)$.

\section{Cell viability assay}

Cell viability was evaluated by MTT assay. Briefly, cells were plated at a density of $3 \times 10^{4}$ cells/well in 96-well plate and incubated for $24 \mathrm{~h}$. The cells were treated with TC-HW at the indicated concentrations for $24 \mathrm{~h}$. Then, the cells were incubated with $50 \mu$ of MTT solution $(1 \mathrm{mg} / \mathrm{ml})$ for an additional $2 \mathrm{~h}$. The resulting crystals were dissolved in DMSO. The formation of formazan was measured by reading absorbance at a wavelength of $570 \mathrm{~nm}$ using UV/Visible spectrophotometer (Human Cop., Xma-3000PC, Seoul, Korea).

\section{Measurement of intracellular ROS}

Measurement of intracellular ROS was performed using OxiSelect $^{\mathrm{Tm}}$ Intracellular ROS Assay Kit (Cell Biolabs, Inc., San Diego, CA). Briefly, HCT116 and SW480 cells were plated at a density of $3 \times 10^{4}$ cells/well in 96-well plate and incubated for $24 \mathrm{~h}$. The cells were treated with TC-HW at the indicated concentrations for $24 \mathrm{~h}$ and then washed with $1 \times$ phosphate-buffered saline (PBS). Then, the cells were stained with $100 \mu \mathrm{l}$ of $1 \times$ dichlorofluorescein diacetate (DCFH-DA)/media solution at $37{ }^{\circ} \mathrm{C}$ for $1 \mathrm{~h}$. After three washing with $1 \times \mathrm{PBS}$, the cells were lysed with $100 \mu \mathrm{l}$ of $2 \times$ cell lysis buffer, incubated for $5 \mathrm{~min}$ and then the fluorescence was recorded at 
$480 \mathrm{~nm}$ excitation/530 $\mathrm{nm}$ emission in an enzymelinked immunosorbent assay plate reader (Human Cop., Xma-3000PC, Seoul, Korea).

\section{Cell cycle analysis}

HCT116 cells were plated at a density of $1 \times 10^{6}$ cells/ well in 6-well plate and incubated for $24 \mathrm{~h}$. The cells were treated with TC-HW for $24 \mathrm{~h}$. After then, the cells were dissociated with trypsin, washed in cold PBS and fixed with $70 \%$ cold ethanol on ice for $30 \mathrm{~min}$. The suspensions were centrifuged at $1500 \mathrm{rpm}$ for $5 \mathrm{~min}$. The pellets were resuspended in a solution containing $50 \mu \mathrm{g} /$ $\mathrm{ml}$ propidium iodide, $1 \mathrm{mg} / \mathrm{ml}$ sodium citrate, $0.3 \mathrm{ml}$ nonidet P-40 and $5 \mu \mathrm{g} / \mathrm{ml}$ RNase A and stayed on ice at least $40 \mathrm{~min}$. Then the pellets were analyzed by a flow cytometer.

\section{Isolation of cytosol and nucleus fraction}

Cytosol and nuclear fractions of cells were prepared using a nuclear extract kit (Active Motif, Carlsbad, CA, USA) according to the manufacturer's protocols. Briefly, HCT116 cells after TC-HW treatment were harvested with $1 \times$ cold hypotonic buffer and incubated at $4{ }^{\circ} \mathrm{C}$ for $15 \mathrm{~min}$. After adding detergent and vortexing for $10 \mathrm{~s}$, the cells were centrifuged at $14,000 \mathrm{~g}$ for $1 \mathrm{~min}$ at $4{ }^{\circ} \mathrm{C}$ and the supernatants (cytoplasmic fraction) were collected and stored at $-80{ }^{\circ} \mathrm{C}$ for further analysis. The cell pellets were used for nuclear fraction collection. Cell pellets were re-suspended with complete lysis buffer by pipetting up and down, and incubated at $4{ }^{\circ} \mathrm{C}$ for $30 \mathrm{~min}$ under shaking. After $30 \mathrm{~min}$, nuclear suspensions were centrifuged at $14,000 \mathrm{~g}$ for $10 \mathrm{~min}$ at $4{ }^{\circ} \mathrm{C}$, and the supernatants (nuclear fraction) were stored at $-80{ }^{\circ} \mathrm{C}$ for further analysis.

\section{SDS-PAGE and western blot}

Cells were plated at a density of $2 \times 10^{6}$ cells/well in 6well plate and grown to $80 \%$ confluence. After treatment, the cells were washed with $1 \times$ phosphate-buffered saline (PBS), and lysed in radioimmunoprecipitation assay (RIPA) buffer (Boston Bio Products, Ashland, MA, USA) supplemented with protease inhibitor cocktail (Sigma-Aldrich) and phosphatase inhibitor cocktail (Sigma-Aldrich), and centrifuged at $15,000 \times \mathrm{rpm}$ for $10 \mathrm{~min}$ at $4{ }^{\circ} \mathrm{C}$. Protein concentration was determined by the bicinchoninic acid (BCA) protein assay (Pierce, Rockford, IL, USA). The proteins were separated on SDS-PAGE and transferred to PVDF membrane (BioRad Laboratories, Inc., Hercules, CA, USA). The membranes were blocked for non-specific binding with $5 \%$ non-fat dry milk in Tris-buffered saline containing $0.05 \%$ Tween 20 (TBS-T) for $1 \mathrm{~h}$ at room temperature and then incubated with specific primary antibodies in $5 \%$ non-fat dry milk at $4{ }^{\circ} \mathrm{C}$ overnight. After three washes with TBS-T, the blots were incubated with horse radish peroxidase (HRP)-conjugated immunoglobulin G (IgG) for $1 \mathrm{~h}$ at room temperature and chemiluminescence was detected with ECL Western blotting substrate (Amersham Biosciences, Piscataway, NJ, USA) and visualized in Polaroid film.

\section{Reverse transcriptase-polymerase chain reaction (RT-PCR)}

After treatment, total RNA was prepared using a RNeasy Mini Kit (Qiagen, Valencia, CA, USA) and total RNA $(1 \mu \mathrm{g})$ was reverse-transcribed using a Verso cDNA Kit (Thermo Scientific, Pittsburgh, PA, USA) according to the manufacturer's protocol for CDNA synthesis. PCR was carried out using PCR Master Mix Kit (Promega, Madison, WI, USA) with human primers for cyclin D1, $\beta$-catenin, TCF4, ATF3 and GAPDH as followed: cyclin D1: forward $5^{\prime}$-aactacctggaccgcttcct-3' and reverse $5^{\prime}$-ccacttgagcttgtt cacca-3', $\beta$-catenin: forward $5^{\prime}$-cccactaatgtccagcgttt- 3 ' and reverse $5^{\prime}$-aatccactggtgaaccaagc- $3{ }^{\prime}$, TCF4: forward $5^{\prime}$ ttcaaagacgacggcgaacag- $3^{\prime}$ and reverse $5^{\prime}$-ttgctgtacgtgataa gaggcg-3', ATF3: forward 5' -gtttgaggattttgctaacctgac-3', and reverse $5{ }^{\prime}$-agctgcaatcttatttcttctcgt-3', GAPDH: forward $5^{\prime}$-acccagaagactgtggatgg- $3^{\prime}$ and reverse $5^{\prime}$-ttcta gacggcaggtcaggt- 3 '. The following PCR reaction conditions were used: 1 cycle of ( $3 \mathrm{~min}$ at $94{ }^{\circ} \mathrm{C}$ for denaturation), 25 cycles of $\left(30 \mathrm{~s}\right.$ at $94{ }^{\circ} \mathrm{C}$ for denaturation, $30 \mathrm{~s}$ at $60{ }^{\circ} \mathrm{C}$ for annealing, and $30 \mathrm{~s}$ at $72{ }^{\circ} \mathrm{C}$ for elongation), and 1 cycle of $\left(5 \mathrm{~min}\right.$ for extension at $\left.72^{\circ} \mathrm{C}\right)$.

\section{Transfection of small interference RNA (siRNA)}

HCT116 cells were seeded and incubated overnight. HCT116 cells were transfected with control siRNA, p65 siRNA or ATF3 siRNA for $48 \mathrm{~h}$ at a concentration of $100 \mathrm{nM}$ using TransIT-TKO transfection reagent (Mirus, Madison, WI, USA) according to the manufacturer's instruction. Then HCT116 cells were treated with TC-HW $(100 \mu \mathrm{g} / \mathrm{ml})$ for $24 \mathrm{~h}$.

\section{Expression vectors}

HA-tagged wild type cyclin D1 and HA-tagged T286A cyclin D1 were provided from Addgene (Cambridge, MA, USA). Transient transfection of the vectors was performed using the PolyJet DNA transfection reagent (SignaGen Laboratories, Ijamsville, MD, USA) according to the manufacturers' instruction.

\section{Transient transfection and luciferase activity}

Transient transfection for luciferase activity was carried out using the PolyJet DNA transfection reagent (SignaGen Laboratories, Ijamsville, MD, USA) according to the manufacturers' instruction. Cells were seeded in 12-well plates at a concentration of $2 \times 10^{5}$ cells/well. After growth overnight, plasmid mixtures containing $1 \mu \mathrm{g}$ of the luciferase constructs (Addgene, Cambridge, MA, USA) and $0.1 \mu \mathrm{g}$ 
of pRL-null vector were transfected for $24 \mathrm{~h}$. The transfected cells were treated with TC-HW for $24 \mathrm{~h}$. The cells were then harvested in $1 \times$ luciferase lysis buffer, and luciferase activity was normalized to the pRL-null luciferase activity using a dual-luciferase assay kit (Promega, Madison, WI, USA).

\section{GC/MS analysis of the active chemical compounds}

GC-MS analysis was performed using same GC-MSD, equipped with a Ultra-2 (Crosslinked 5\% PH ME Siloxane, 25 m length $\times 0.20 \mathrm{~mm}$ i.d. Hewlett packard, USA). The carrier gas used was helium, at a constant flow rate of $1.0 \mathrm{ml} / \mathrm{min}$. One microliter of the extract was injected into the column using 10:1 of the split ratio injection mode. The oven temperature was initially held at $100{ }^{\circ} \mathrm{C}$ for $0 \mathrm{~min}$, then raised to $280{ }^{\circ} \mathrm{C}$ at a rate of $3{ }^{\circ} \mathrm{C} / \mathrm{min}$ for $50 \mathrm{~min}$, and finally held at $280{ }^{\circ} \mathrm{C}$ for $5 \mathrm{~min}$. The temperatures of injector and detector were $200{ }^{\circ} \mathrm{C}$ and $240{ }^{\circ} \mathrm{C}$, respectively. The mass detector was operated in electron impact mode with an ionization energy of $70 \mathrm{eV}$, a scanning range of 33-550 a.m.u. and a scan rate of 1.4 scans/s. Components of the extracts were identified with the aid of the Wiley 275 Imass spectral database (Hewlett-Packard, 1995) or by manual interpretation.

\section{Statistical analysis}

All the data are shown as mean \pm SEM (standard error of mean). Statistical analysis was performed with oneway ANOVA followed by Dunnett's test. Differences with ${ }^{*} P<0.05$ were considered statistically significant.

\section{Results}

Effect of TC-HW on the cell viability and cyclin D1 protein level in HCT116 and SW480 cells

To evaluate whether TC-HW reduces cell viability in human colorectal cancer cell lines, HCT116, SW480, LoVo and HT-29 cells, MTT assay was performed. As shown in Fig. 1a, TC-HW reduced the cell viability by $16.3 \%$ and $23.0 \%$ at $50 \mu \mathrm{g} / \mathrm{ml}, 54.0 \%$ and $47.4 \%$ at $100 \mu \mathrm{g} / \mathrm{ml}$, and $83.5 \%$ and $63.6 \%$ at $200 \mu \mathrm{g} / \mathrm{ml}$ in HCT116 and SW480 cells, respectively. In addition, we observed that the viability of LoVo and HT-29 cells was dose-dependently reduced by TC-HW treatment. However, TC-HW did not affect the cell viability in the normal cells (Fig. 1a). Because cell growth arrest contributes to the decrease of the cell viability, we investigated whether TC-HW modulates cyclin D1 protein level in HCT116 and SW480 cells because cyclin D1 has been regarded as one of the proteins regulating the cell proliferation. As a result, cyclin D1 protein level was decreased by TC-HW treatment at the dose-dependent manner in HCT116 and SW480 cells (Fig. 1b). Because cyclin D1 protein level is regulated by gene amplification [16], we investigated whether TC-HW affects cyclin D1 transcription. As shown in Fig. 1c, TC-HW treatment downregulated the expression of cyclin D1 mRNA. TCHW-mediated downregulation of cyclin D1 at the protein and mRNA level was observed in LoVo and HT-29 cells (Fig. 1d and e). We investigated whether the TCHW-mediated downregulation of cyclin D1 contributes to the cell cycle arrest. As shown in Fig. 1f, the majority of HCT116 cells without TC-HW were in S phase. However, TC-HW dose-dependently induced the accumulation of G0/G1 phase in HCT116 cells. We observed that the downregulation of cyclin D1 protein level by TCHW is more dramatically showed than the change of cyclin D1 mRNA level, which indicates that TC-HW may affect cyclin D1 protein stability. To determine whether TC-HW may induce cyclin D1 proteasomal degradation, HCT116 and SW480 cells were pretreated with MG132 as a proteasome inhibitor and then cotreated with TC-HW. As shown in Fig. 1g, cyclin D1 protein level was decreased by TC-HW in absence of MG132. However, the presence of MG132 restored TCHW-mediated cyclin D1 downregulation. These data suggest that TC-HW-mediated downregulation of cyclin D1 may result from both inhibition of cyclin D1 transcription and induction of cyclin D1 proteasomal degradation.

TC-HW mediated cyclin D1 degradation is dependent on GSK3 $\beta$-dependent threonine-286 (T286) of cyclin D1

There is growing evidence that cyclin D1 degradation is a consequence of T286 phosphorylation of cyclin D1 protein [17]. Thus, we firstly investigated whether TC induces T286 phosphorylation of cyclin D1. As shown in Fig. 2a, TC-HW phosphorylated cyclin D1 T286 at $1 \mathrm{~h}$ after the treatment. Next, we determined that the mutation of cyclin D1 T286 affects TC-HW-mediated cyclin D1 degradation. As a result, cyclin D1 was degraded by TC-HW in the cells transfected with wild-type cyclin D1, while TC-HW-mediated cyclin D1 degradation was attenuated in the cells transfected with T286A-cyclin D1 (Fig. 2b). These data indicate that cyclin D1 degradation by TC-HW may be a consequence of T286 phosphorylation of cyclin D1.

GSK3 $\beta$-dependent T286 phosphorylation of cyclin D1 has been known to be involved in cyclin D1 degradation [17-19]. Thus, $\mathrm{LiCl}$ as a GSK3 $\beta$ inhibitor was applied for determining whether TC-HW-mediated cyclin D1 degradation is GSK3 $\beta$-dependent. As shown in Fig. 2c and $\mathrm{d}$, TC-HW degraded cyclin D1 protein in absence of $\mathrm{LiCl}$, while cyclin D1 degradation by $\mathrm{TC}-\mathrm{HW}$ was attenuated in presence of $\mathrm{LiCl}$. In addition, we observed that the inhibition of GSK3 $\beta$ by $\mathrm{LiCl}$ attenuated T286 phosphorylation of cyclin D1 induced by TC-HW in HCT116 and SW480 cells (Fig. 2e and f). These data indicate that TC-HW may induce GSK3 $\beta$-dependent T286 


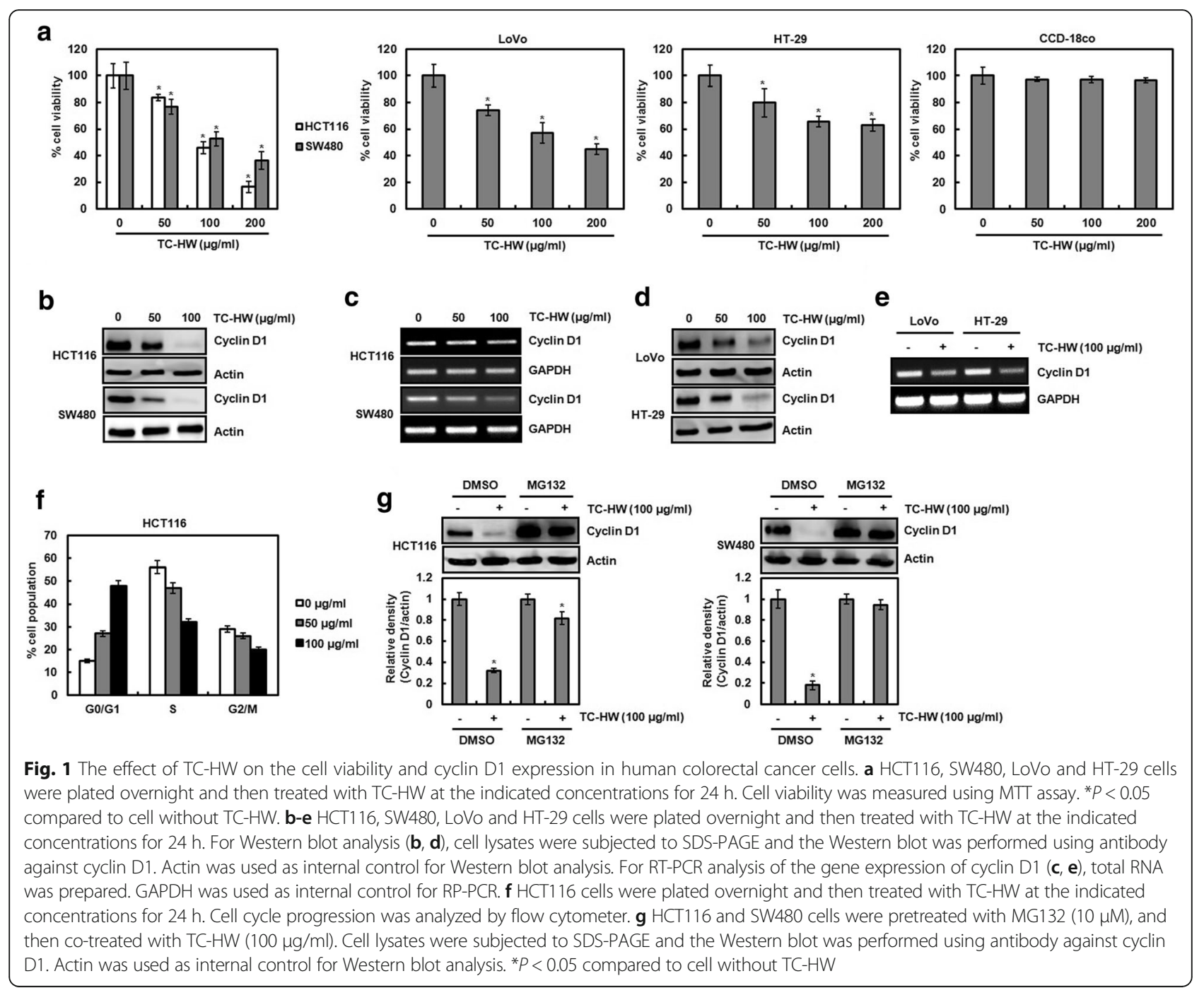

phosphorylation of cyclin D1 and subsequently degrade cyclin D1 protein.

Although ERK1/2 and p38 has been reported to be associated with cyclin D1 degradation [20, 21], TC-HW induced cyclin D1 degradation in absence/presence of PD98059 as an ERK1/2 inhibitor and SB203580 as a p38 inhibitor (data not shown).

\section{TC-HW inhibits Wnt activation}

In this study, we observed that TC-HW suppresses cyclin D1 transcriptional activity (Fig. 1c). Because Wnt signaling has been reported to be associated with cyclin D1 transcription [22], we investigated whether TC-HW regulates Wnt activation. As a result, TC-HW treatment resulted in the decrease of $\beta$-catenin and TCF4 in both protein and mRNA level (Fig. $3 a$ and b), which contributed to the inhibition of $\beta$-catenin/TCF-dependent luciferase activity (Fig. 3c). These data indicate that TC-HW may suppress cyclin D1 transcription through inhibiting
Wnt activation via downregulation of $\beta$-catenin and TCF4.

\section{TC-HW induces ROS-dependent apoptosis}

Apoptosis as well as the cell growth arrest has been involved in the reduction of the cell viability. Thus, we determined whether TC-HW induces apoptosis in human colorectal cancer cells. As shown in Fig. 4a, cleavage of PARP as an apoptotic marker was increased in TC-HWtreated HCT116 and SW480 cells at the dose-dependent manner. In addition, we observed that TC-HW treatment increases the intracellular ROS level in HCT116 and SW480 cells (Fig. 4b).

There is growing evidence that ROS-mediated apoptosis is associated with DNA damage [23-26]. Thus, the effect of TC-HW on DNA damage was investigated, and we observed that TC-HW increases the phosphorylation of H2AX as a DNA damage marker (Fig. 4c). These data suggest the hypothesis that TC-HW may reduce the cell 


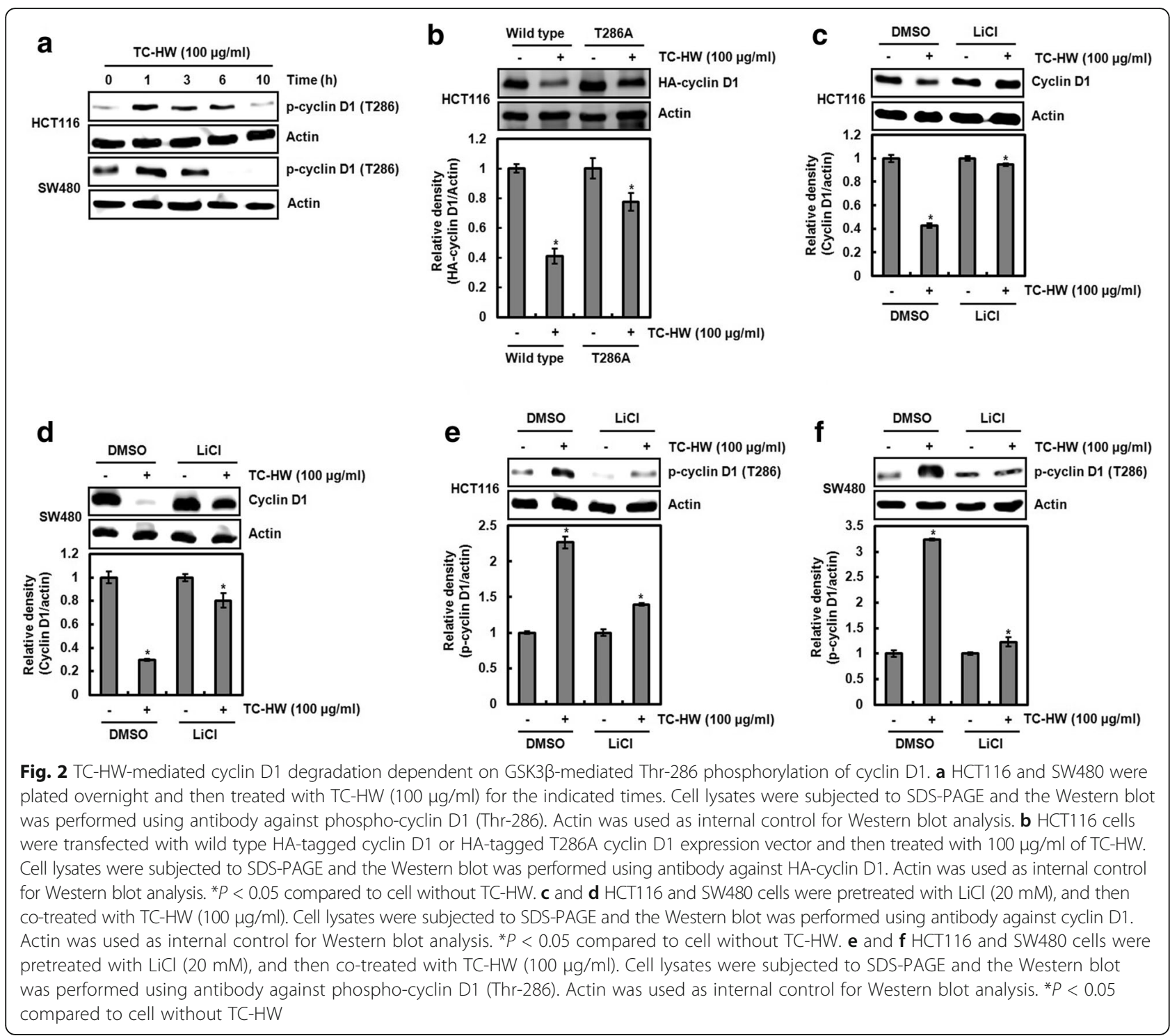

viability through inducing apoptosis via ROS-mediated DNA damage. To elucidate this hypothesis, we investigated the effect of TC-HW on PARP cleavage, cell viability and phosphorylation of H2AX under ROS scavenging by $\mathrm{N}$-acetyl-1-cysteine (NAC). As shown in Fig. 4d-f, the presence of NAC attenuated the cleavage of PARP, reduction of the cell viability, and phosphorylation of H2AX mediated by TC-HW.

ROS-dependent activation of NF- $\mathrm{KB}$ contributes apoptosis ROS-mediated NF- $\mathrm{kB}$ activation was reported to induce apoptosis in human colorectal cancer cells [27-29]. Thus, we investigated the relationship between TC-HWmediated ROS, NF-kB activation, and apoptosis. Firstly, we observed that TC-HW dose-dependently increases NF-kB luciferase activity (Fig. 5a), while NAC treatment blocks
NF- $k B$ activation by TC-HW (Fig. 5b). NF- $k B$ activation is regulated by p65 nuclear accumulation through IкB- $\alpha$ degradation [30]. As shown in Fig. $5 \mathrm{c}$ and d, IkB- $\alpha$ degradation and subsequent p65 nuclear accumulation by TC-HW treatment were attenuated in presence of NAC. These data indicate that TC-HW-mediated ROS may contribute to $\mathrm{NF}-\kappa \mathrm{B}$ activation. Lastly, we determined whether NF- $\mathrm{kB}$ activation is essential for the TC-HW-mediated apoptosis. As shown in Fig. 5e, p65 knockdown by p65 siRNA decreased TC-HW-mediated cleavage of PARP compared to the cell transfected with control-siRNA.

\section{ROS-dependent activation of activating transcription} factor 3 (ATF3) contributes to apoptosis

It has been reported that activating transcription factor 3 (ATF3) is one of the target proteins for ROS and ROS- 

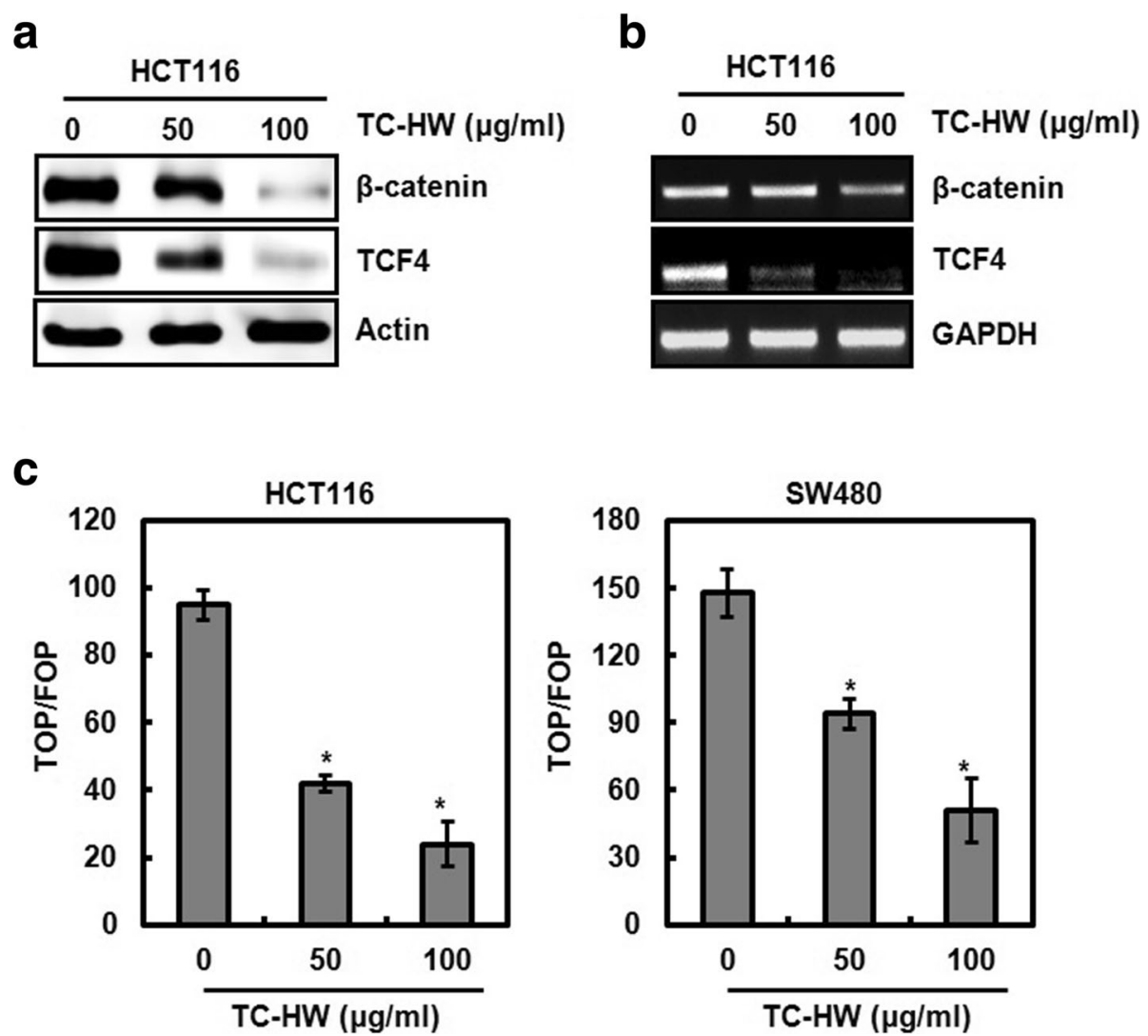

Fig. $\mathbf{3}$ Inhibition of cyclin D1 transcription by TC-HW through the inhibition of Wnt activation. $\mathbf{a}$ and $\mathbf{b}$ HCT116 and SW480 cells were treated with TC-HW at the indicated concentrations for $24 \mathrm{~h}$. For Western blot analysis (a), cell lysates were subjected to SDS-PAGE and the Western blot was performed using antibodies against $\beta$-catenin or TCF4. Actin was used as internal control for Western blot analysis. For RT-PCR analysis of the gene expression of $\beta$-catenin and TCF4 (b), total RNA was prepared. GAPDH was used as internal control for RP-PCR. $\mathbf{c}$ HCT116 and SW480 cells were co-transfected with TOP-FLASH or FOP-FLASH constructs containing wild-type or mutated TCF binding sites and pRL-null. The cells were treated with TC-HW for $24 \mathrm{~h}$. Luciferase activity for TOP-FLASH and FOP-FLASH was measured as a ratio of firefly luciferase signal/renilla luciferase signal using a dual luciferase assay kit. ${ }^{*} P<0.05$ compared to cell without TC-HW

mediated ATF3 activation induces apoptosis in human colorectal cancer cells [27]. Thus, we firstly tested whether TC-HW affects ATF3 expression. As shown in Fig. 6a, we observed that TC-HW dose-dependently increases ATF3 in both protein and mRNA level, indicating that TC-HW-mediated overexpression of ATF3 may result from ATF3 transcriptional regulation. In the experiment for TC-HW-mediated ATF3 transcriptional activation, ATF3 promoter activity was dramatically increased by TC-HW treatment (Fig. 6b). Secondly, we determined that TC-HW-mediated ROS affects ATF3 expression and TC-HW-mediated increase of ATF3 protein level and ATF3 promoter activity were decreased in presence of NAC (Fig. 6c and d). Lastly, we investigated that TC-HW-mediated ATF3 expression contributes to the induction of apoptosis, and observed that ATF3 knockdown by ATF3 siRNA blocks TC-HW-mediated cleavage of PARP (Fig. 6e).
GC/MS analysis of the active chemical compounds We analyzed the potential medicinal components with anti-cancer properties from TC-HW using GC/MS. As shown in Fig. 7, cinnamaldehyde $(\mathrm{C} 6 \mathrm{H} 5 \mathrm{CH}=\mathrm{CHCHO}$, MW: 132.16) were identified. Indeed, cinnamaldehyde has been reported to have anti-cancer properties. In the quantitative analysis, $15.4 \%$ of cinnamaldehyde was contained in TC-HW used in this study.

\section{Discussion}

Abnormal cell proliferation induced by altered expression of the protein related with the cell cycle is an important part of cancer development and progression [31]. Thus, the regulation of the cell proliferation has been regarded as an one of the anticancer targets and many anticancer agents have been reported to kill the cancer cells through blocking cancer cell proliferation vis cell cycle arrest [31]. Cyclin-CDK complex has been known to be one of the 


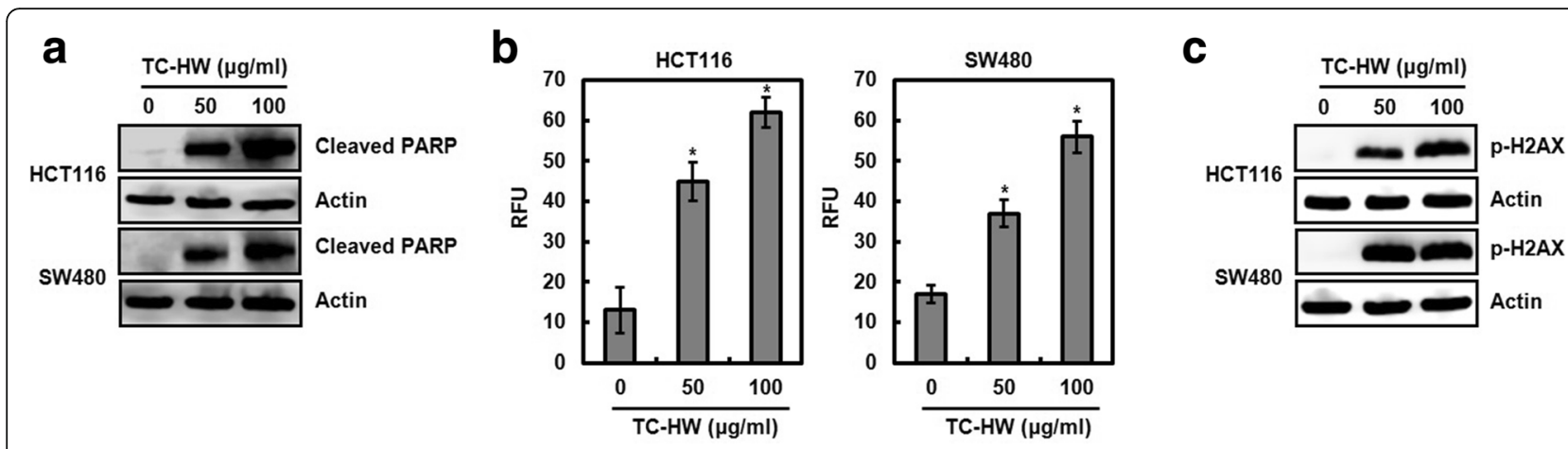

d

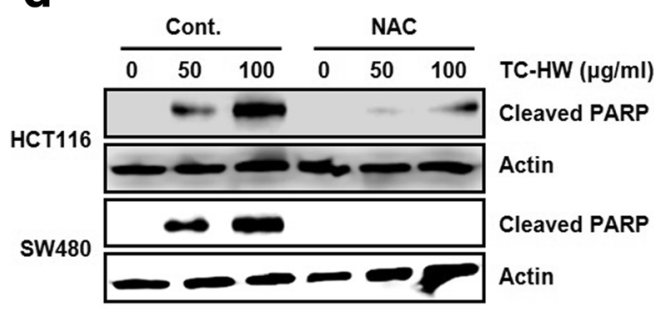

$\mathbf{f}$

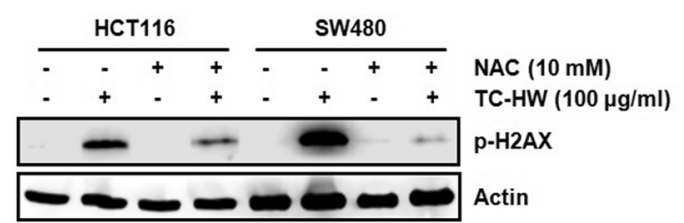

e

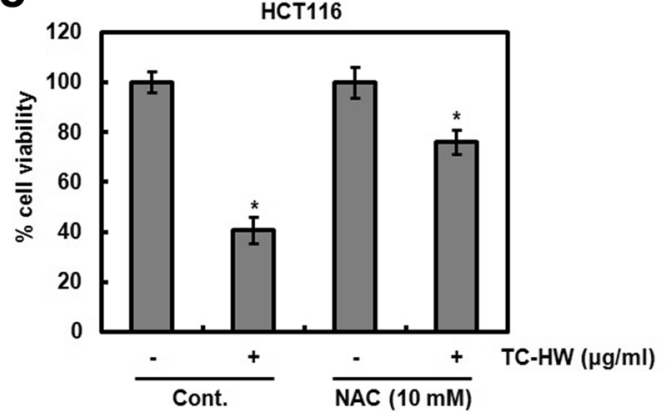

Fig. 4 Induction of apoptosis by TC-HW through ROS-dependent DNA damage. a HCT116 and SW480 were plated overnight and then treated with TC-HW at the indicated concentrations for $24 \mathrm{~h}$. Cell lysates were subjected to SDS-PAGE and the Western blot was performed using antibody against cleaved PARP. Actin was used as internal control for Western blot analysis. b HCT116 and SW480 cells were plated overnight and then treated with TC-HW at the indicated concentrations for $24 \mathrm{~h}$. Intracellular ROS were measured using OxiSelect ${ }^{\mathrm{TM}}$ Intracellular ROS Assay Kit. ${ }^{*} P<0.05$ compared to cell without TC-HW. $\mathbf{c ~ H C T 1 1 6}$ and SW480 were plated overnight and then treated with TC-HW at the indicated concentrations for $24 \mathrm{~h}$. Cell lysates were subjected to SDS-PAGE and the Western blot was performed using antibody against phospho-H2AX. Actin was used as internal control for Western blot analysis. d HCT116 and SW480 were pretreated with NAC (10 mM) and then co-treated with TC-HW at the indicated concentrations. Cell lysates were subjected to SDS-PAGE and the Western blot was performed using antibody against cleaved PARP. Actin was used as internal control for Western blot analysis. e HCT116 and SW480 were pretreated with NAC (10 mM) and then co-treated with TCHW $(100 \mu \mathrm{g} / \mathrm{ml})$. Cell viability was measured using MTT assay. ${ }^{*} P<0.05$ compared to cell without TC-HW. f HCT116 and SW480 were pretreated with NAC $(10 \mathrm{mM})$ and then co-treated with TC-HW $(100 \mu \mathrm{g} / \mathrm{ml})$. Cell lysates were subjected to SDS-PAGE and the Western blot was performed using antibody against phospho-H2AX. Actin was used as internal control for Western blot analysis

regulators associated with the cell cycle progression [32]. Among the cyclin types, cyclin D1 has been observed to be overexpressed in human cancer and cyclin D1-CDK4/6 complex induces the phosphorylation of the retinoblastoma protein, resulting to inducing G1/S transition [16]. Thus, cyclin D1 has been suggested to be one of the important targets for the anti-cancer drug development [16]. Indeed, cyclin D1 overexpression occurs in one-third or more of human colorectal cancers [33].

In this study, we observed that TC-HW downregulates cyclin D1 at both protein and mRNA level in human colorectal cancer cells. For the elucidation of the signaling associated with TC-HW-mediated inhibition of cyclin D1 transcription, we observed that TC-HW suppresses Wnt activation through the downregulation of $\beta$-catenin and TCF4 associated with cyclin D1 gene amplification [22].

In the regulatory effect of TC-HW on cyclin D1 expression, we observed that TC-HW-mediated decrease of cyclin D1 protein level is more dramatic than the change of cyclin D1 mRNA level. These data indicate that cyclin D1 protein stability as well as cyclin D1 transcriptional inhibition may contribute to the downregulation of cyclin D1 protein level. Indeed, there is growing evidence that increased mRNA and protein level account for $2.5 \%$ and $55 \%$ in human colorectal cancer, respectively, which indicates that the upregulated cyclin D1 protein level does not occur 


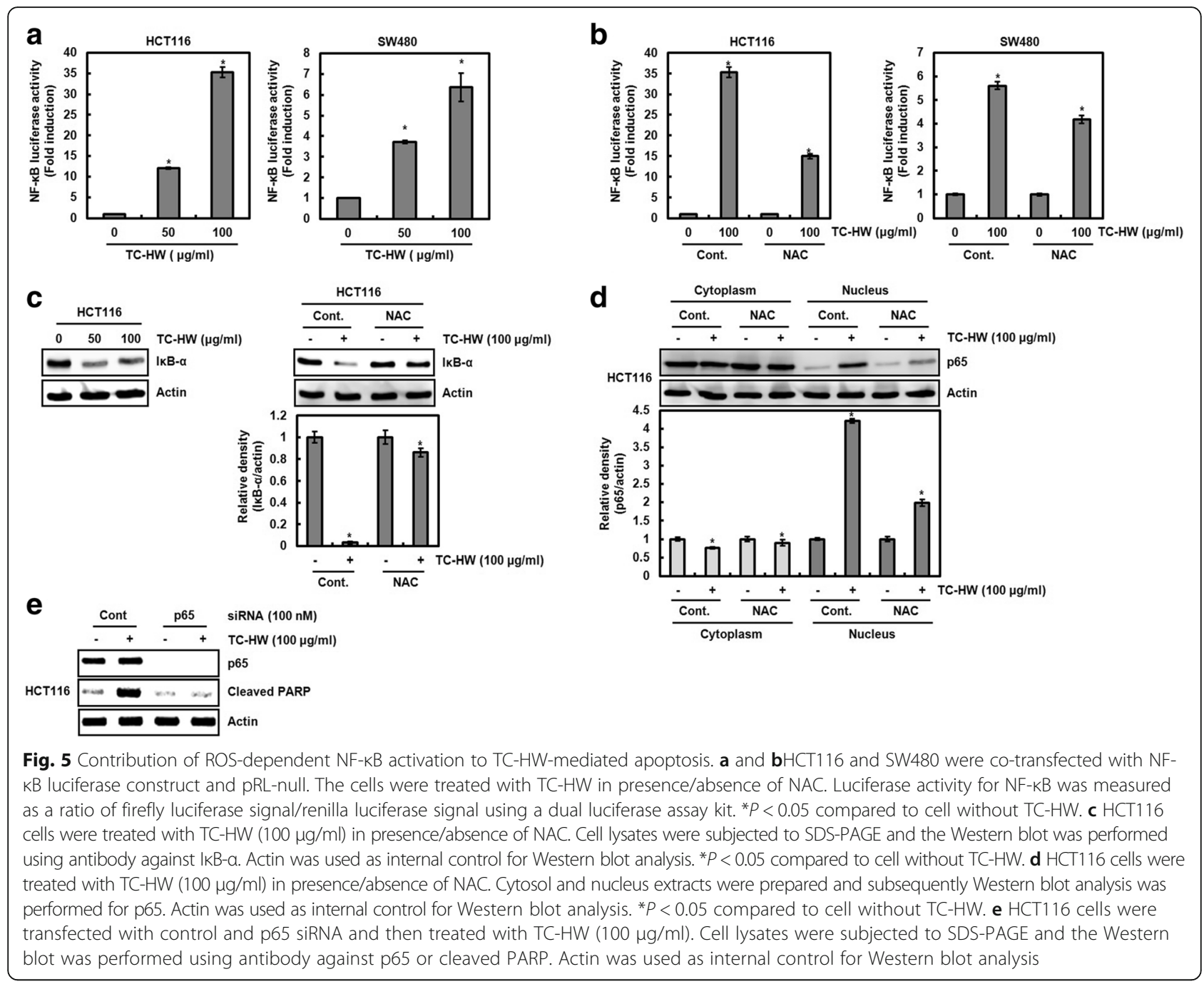

solely as a consequence of gene amplification [16] and the defective post-translational regulation such as the proteasomal degradation may result in the upregulation of cyclin D1 protein level [34, 35]. Thus, induction of cyclin D1 degradation has been regarded as one of the potential anticancer targets [17]. In this study, it was observed that the presence of MG132 as a proteasome inhibitor attenuated TC-HW-mediated decrease of cyclin D1 protein level in HCT116 and SW480 cells, which indicates that TC-HW may induce cyclin D1 degradation.

Cyclin D1 degradation has been reported to be followed by the phosphorylation of cyclin D1 threonine286 (T286) [19, 36]. Defective cyclin D1 degradation by the mutation of Thr-286 contributes to the upregulation of cyclin D1 protein level in several cancers, which results in the significant increase of cyclin D1's oncogenic potential. [17, 37]. Thus, we investigated whether T286 phosphorylation affects TC-HW-mediated cyclin D1 degradation. In this study, TC-HW treatment was observed to phosphorylate T286 of cyclin D1. In addition, the mutation of threonine-286 to alanine (T286A) blocked cyclin D1 degradation by TC-HW. These data suggest that T286 phosphorylation may be an important event for TC-HW-mediated cyclin D1 degradation.

There is growing evidence that glycogen synthase kinase $3 \beta$ (GSK3 $\beta$ ) phosphorylates T286 of cyclin D1 and inhibition of GSK3 $\beta$ activity reduces cyclin D1 degradation $[17,19,38]$. In this study, we observed that inhibition of GSK3 $\beta$ by $\mathrm{LiCl}$ reduces TC-HW-mediated cyclin D1 degradation in HCT116 and SW480. In addition, T286 phosphorylation of cyclin D1 by TC$\mathrm{HW}$ was attenuated in presence of $\mathrm{LiCl}$ as a GSK3 $\beta$ inhibitor. Our data indicates that TC-HW-mediated cyclin D1 degradation may be attributed to GSK3 $\beta$ dependent T286 phosphorylation of cyclin D1.

The inactivation of apoptosis is central to the development of cancer [39] and little apoptosis has been regarded as one of the scenarios in human cancer, which results in malignant cells [40]. Therefore, apoptosis has been used for the cancer treatment of many anticancer 

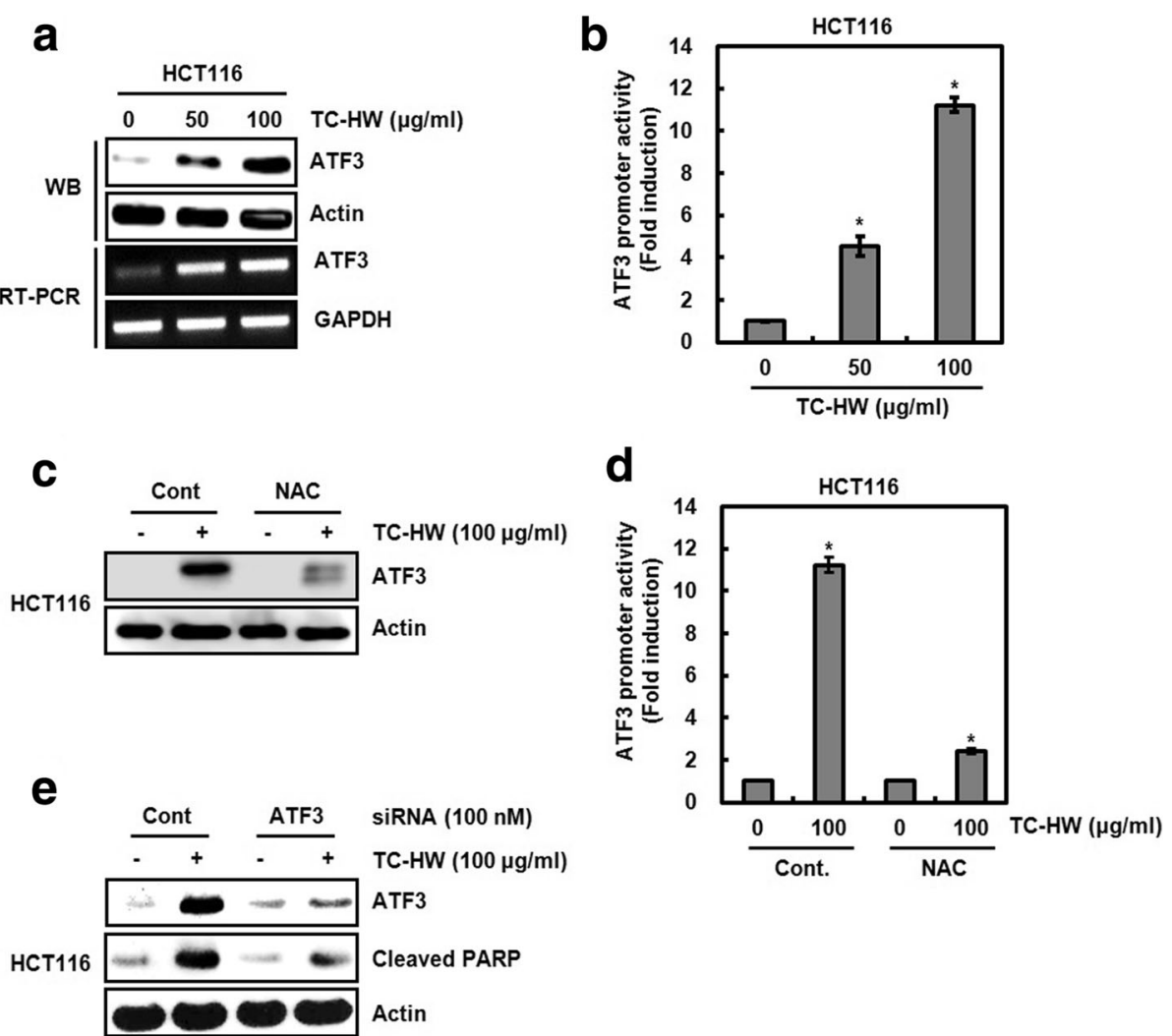

Fig. 6 Contribution of ROS-dependent ATF3 activation to TC-HW-mediated apoptosis. a and $\mathbf{b}$ HCT116 and SW480 cells were treated with TC-HW at the indicated concentrations for $24 \mathrm{~h}$. For Western blot analysis, cell lysates were subjected to SDS-PAGE and the Western blot was performed using antibodies against ATF3. Actin was used as internal control for Western blot analysis. For RT-PCR analysis of the gene expression of ATF3, total RNA was prepared. GAPDH was used as internal control for RP-PCR. $\mathbf{b}$ HCT116 cells were co-transfected with ATF3 promoter and pRL-null for $24 \mathrm{~h}$, and then treated with TC-HW at the indicated concentrations for $24 \mathrm{~h}$. Luciferase activity for ATF3 promoter activity was measured as a ratio of firefly luciferase signal/renilla luciferase signal using a dual luciferase assay kit. ${ }^{*} P<0.05$ compared to cell without TC-HW. c HCT116 cells were treated with TC-HW $(100 \mathrm{\mu g} / \mathrm{ml})$ in presence/absence of NAC. Cell lysates were subjected to SDS-PAGE and the Western blot was performed using antibody against ATF3. Actin was used as internal control for Western blot analysis. d HCT116 cells were co-transfected with ATF3 promoter and pRL-null for $24 \mathrm{~h}$, and then treated with TC-HW $(100 \mathrm{\mu g} / \mathrm{ml})$ in presence/absence of NAC. Luciferase activity for ATF3 promoter activity was measured as a ratio of firefly luciferase signal/renilla luciferase signal using a dual luciferase assay kit. ${ }^{*} P<0.05$ compared to cell without TC-HW. e HCT116 cells were transfected with control and ATF3 siRNA and then treated with TC-HW $(100 \mu \mathrm{g} / \mathrm{ml})$. Cell lysates were subjected to SDS-PAGE and the Western blot was performed using antibody against ATF3 or cleaved PARP. Actin was used as internal control for Western blot analysis

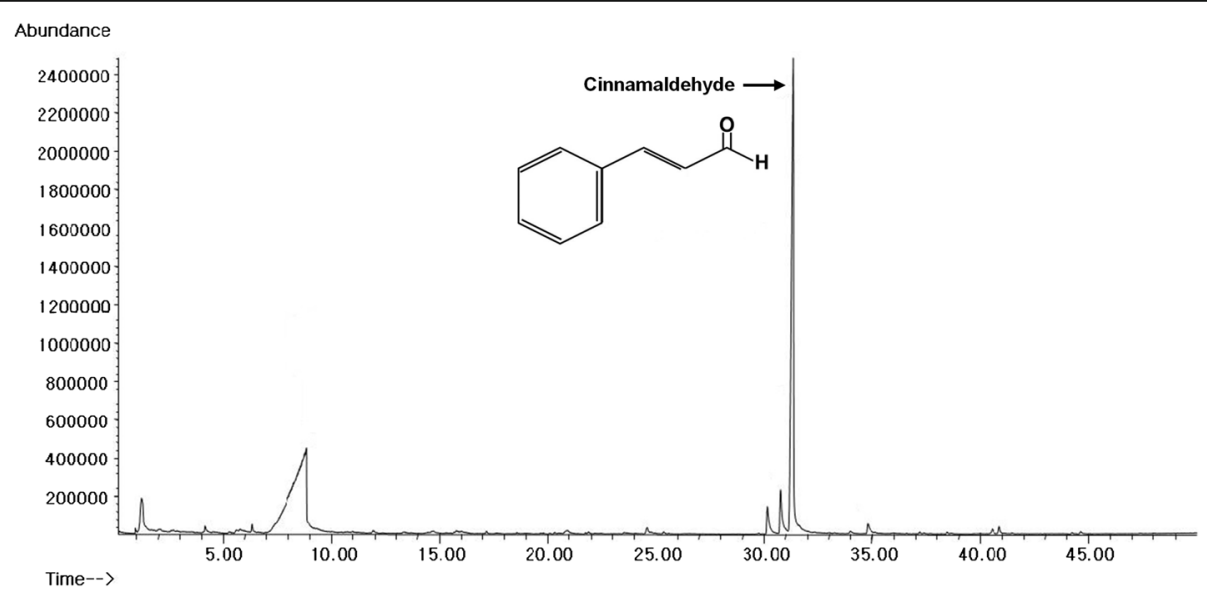

Fig. 7 The chromatography of GC/MS analysis of TC-HW 


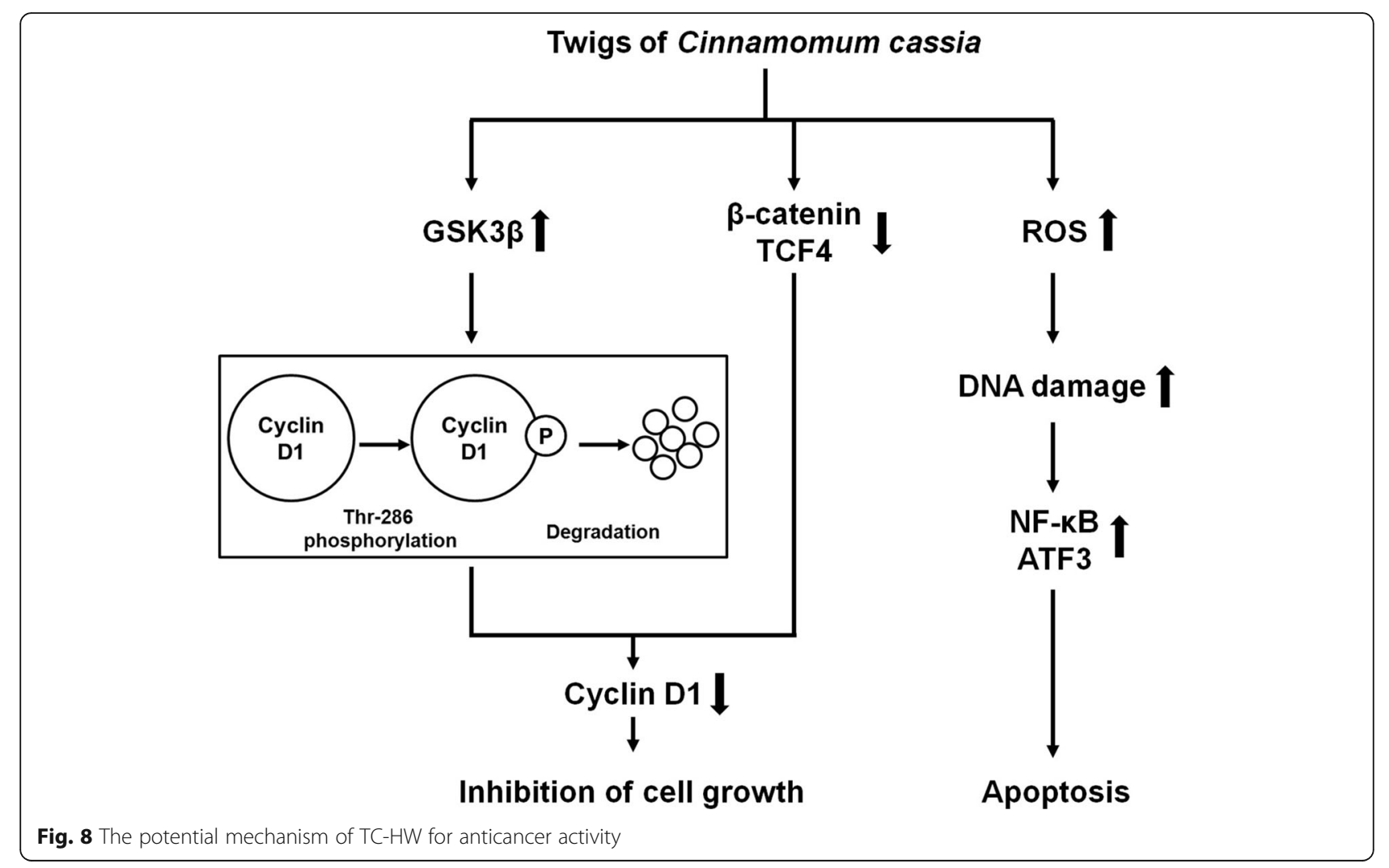

agents [40]. Although apoptosis can be regulated by many complex pathways, reactive oxygen species (ROS) have been known to be one of many factors regulating apoptosis [41]. Disproportionate ROS induce DNA damage, which contributes to the induction of apoptosis in human cancer [23-26]. Thus, increase of intracellular ROS has been regarded as one of the targets for the cancer treatment [41]. In this study, TC-HW dosedependently increased the cleavage of PARP, indicating that TC-HW may induce apoptosis in human colorectal cancer cells. In the study for the effect of ROS on TCHW-mediated apoptosis, we observed that TC-HW increases ROS level and phosphorylates $\mathrm{H} 2 \mathrm{AX}$ as a DNA damage marker. In addition, the presence of N-acetyl-lcysteine (NAC) as a ROS scavenger attenuated TC-HWmediated PARP cleavage and H2AX phosphorylation. These data indicate that TC-HW-mediated apoptosis may be a consequence of ROS-dependent DNA damage.

ROS-induced DNA damage can activate NF- $\mathrm{kB}$ signaling, resulting in the induction of apoptosis [27-29]. In addition, ROS increase the expression of activating transcription factor 3 (ATF3) and ROS-mediated ATF3 activation induces apoptosis in human colorectal cancer cells [27]. Therefore, we examined if TC-HW-induced ROS directly affects the activation of NF- $\mathrm{kB}$ and ATF3, which induces apoptosis in human colorectal cancer cell. TC-HW increased NF- $\mathrm{KB}$ transcriptional activity, while the presence of NAC blocked
NF- $\mathrm{kB}$ activation by TC-HW. We observed that TC-HWmediated NF-кB activation is followed by $\mathrm{p} 65$ nuclear accumulation through ROS-dependent degradation of IкB- $\alpha$. In addition, inhibition of NF- $\mathrm{kB}$ activation by $\mathrm{p} 65$ siRNA attenuated TC-HW-mediated apoptosis. These findings suggest that ROS-dependent NF- $\mathrm{kB}$ activation may contribute to TC-HW-mediated apoptosis. In the effect of TC-HW on ATF3-mediated apoptosis, TC-HW increased ATF3 expression through upregulating ATF3 transcriptional activity. However, pretreatment of NAC reduced TC-HW-mediated increase of ATF3 protein level and ATF3 transcriptional activity. In addition, knockdown of ATF3 by ATF3 siRNA attenuated TC-HW-mediated apoptosis.

\section{Conclusion}

In conclusion, TC-HW downregulates cyclin D1 protein level through cyclin D1 degradation via GSK3 $\beta$-dependent T286 phosphorylation, and TC-HW-mediated inhibition of Wnt activation by the downregulation of $\beta$-catenin and TCF4 contributes to decrease of cyclin D1 protein level through the inhibition of cyclin D1 transcription (Fig. 8). In addition, TC-HW induces apoptosis through ROSdependent activation of NF-kB and ATF3 (Fig. 8). This study may support the anti-cancer property of TC-HW and our data will provide the complementary and alternative use of TC-HW for cancer treatment. 


\section{Abbreviations}

ATF3: Activating transcription factor 3; DMSO: Dimethyl sulfoxide; ERK1/ 2: Extracellular signal-regulated kinase 1/2; GSK3 $\beta$ : Glycogen synthase kinase 33; IKB-a: Inhibitor of kappa B-a; MTT: 3-(4,5-dimethylthizaol-2-yl)-2,5-diphenyl tetrazolium bromide; NAC: N-acetyl-L-cysteine; NF-KB: Nuclear factor-kappa B; ROS: Reactive oxygen species; RT-PCR: Reverse transcriptase-polymerase chain reaction; SiRNA: Small interfering RNA; T286A: Threonine-286 to alanine; TC: Twigs of Cinnamomum cassia; TCF4: T-cell factor-4; TC-HW: Hot water extracts from twigs of Cinnamomum cassia; Thr286: Threonine-286

\section{Acknowledgements}

The authors would like to thank all of the colleagues and students who contributed to this study.

\section{Funding}

This research was supported by Basic Science Research Program through the National Research Foundation of Korea (NRF) funded by the Ministry of Education (NRF-2016R1D1A3B03931713).

\section{Availability of data and materials}

Data are all contained within the paper.

\section{Authors' contributions}

JBJ directed and JBJ and HSK designed the study. GHP, HMS, SBP, HJS and YU performed the experiments. SBP and GHP drafted manuscript. JBJ and HSK corrected the manuscript. All authors read and approved the final manuscript.

\section{Ethics approval and consent to participate}

Not applicable.

\section{Consent for publication}

Not applicable.

\section{Competing interests}

The authors declare that they have no competing interests.

\section{Publisher's Note}

Springer Nature remains neutral with regard to jurisdictional claims in published maps and institutional affiliations.

\section{Author details}

${ }^{1}$ Forest Medicinal Resources Research Center, National Institute of Forest Science, Yeongju 36040, Republic of Korea. ${ }^{2}$ Department of Medicinal Plant Resources, Andong National University, Andong 36729, Republic of Korea. ${ }^{3}$ Department of Food Science \& Biotechnology, Kyonggi University, Suwon 16227, Republic of Korea. ${ }^{4}$ Insititute of Agricultural Science and Technology, Andong National University, Andong 36729, Republic of Korea.

Received: 13 September 2017 Accepted: 16 January 2018 Published online: 25 January 2018

\section{References}

1. Brenner H, Kloor M, Pox CP. Colorectal cancer. Lancet. 2014;383(9927):1490-502.

2. Schmoll HJ, Stein A. Colorectal Cancer in 2013: towards improved drugs, combinations and patient selection. Nat Rev Clin Oncol. 2014;11(2):79-80.

3. Kuipers EJ, Rosch T, Bretthauer M. Colorectal cancer screening-optimizing current strategies and new directions. Nat Rev Clin Oncol. 2013;10(3):130-42

4. Brouquet A, Nordlinger B. Metastatic colorectal cancer outcome and fatty liver disease. Nat Rev Gastroenterol Hepatol. 2013:10(5):266-7.

5. Li W, Zheng H, Bukuru J, De Kimpe N. Natural Medicines used in the traditional Chinese medical system for therapy of diabetes mellitus. J Ethnopharmacol. 2004;92:1-21.

6. Ji HF, Li XJ, Zhang HY. Natural products and drug discovery. Can thousands of years of ancient medical knowledge lead us to new and powerful drug combinations in the fight against cancer and dementia? EMBO Rep. 2009; 10(3):194-200.

7. Sung YY, Yoon T, Jang JY, Park SJ, Jeong GH, Kim HK. Inhibitory effects of Cinnamomum cassia extract on atopic dermatitis-like skin lesions induced by mite antigen in NC/Nga mice. J Ethnopharmacol. 2011;133(2):621-8.
8. Kim JH. Extraction time and temperature affect the extraction efficiencies of coumarin and phenylpropanoids from Cinnamomum cassia bark using a microwave-assisted extraction method. J Chromatogr B. 2017;1063:196-203.

9. Shimada Y, Goto H, Kogure T, Kohta K, Shintani T, Itoh T, Terasawa K. Extract prepared from the bark of Cinnamomum cassia Blume prevents glutamateinduced neuronal death in cultured cerebellar granule cells. Phytother Res. 2000;14(6):466-8.

10. Lee HS, Kim BS, Kim MK. Suppression effect of Cinnamomum cassia barkderived component on nitric oxide synthase. J Agric Food Chem. 2002; 50(26):7700-3.

11. Koppikar SJ, Choudhari AS, Suryavanshi SA, Kumari S, Chattopadhyay S, Kaul-Ghanekar R. Aqueous cinnamon extract (ACE-c) from the bark of Cinnamomum cassia causes apoptosis in human cervical cancer cell line (SiHa) through loss of mitochondrial membrane potential. BMC Cancer. 2010;10:210.

12. Kang BH, Racicot K, Pilkenton SJ, Apostolidis E. Evaluation of the in vitro anti-hyperglycemic effect of Cinnamomum cassia derived phenolic phytochemicals, via carbohydrate hydrolyzing enzyme inhibition. Plant Foods Hum Nutr. 2014;69(2):155-60.

13. Ooi LS, Li Y, Kam SL, Wang H, Wong EY, Ooi VE. Antimicrobial activities of cinnamon oil and cinnamaldehyde from the Chinese medicinal herb Cinnamomum cassia Blume. Am J Chin Med. 2006;34(3):511-22.

14. NMA C, Tariq P. Anti-microbial activity of Cinnamomum cassia against diverse microbial flora with its nutritional and medicinal impacts. Pak J Bot. 2006;38:169

15. Ngoc TM, Khoi NM, Ha do T, Nhiem NX, Tai BH, Don DV, Luong HV, Son DC, Bae K. Xanthine oxidase inhibitory activity of constituents of Cinnamomum cassia twigs. Bioorg Med Chem Lett. 2012;22(14):4625-8.

16. Musgrove EA, Caldon CE, Barraclough J, Stone A, Sutherland RL. Cyclin D as a therapeutic target in cancer. Nat Rev Cancer. 2011;11:558-72.

17. Alao JP. The regulation of cyclin D1 degradation: roles in cancer development and the potential for therapeutic invention. Mol Cancer. 2007;6:24.

18. Alt JR, Cleveland JL, Hannink M, Diehl JA. Phosphorylation-dependent regulation of cyclin D1 nuclear export and cyclin D1-dependent cellular transformation. Genes Dev. 2000;14(24):3102-14.

19. Diehl JA, Cheng M, Roussel MF, Sherr CJ. Glycogen synthase kinase-3beta regulates cyclin D1 proteolysis and subcellular localization. Genes Dev. 1998; 12(22):3499-511.

20. Okabe H, Lee SH, Phuchareon J, Albertson DG, McCormick F, Tetsu O. A critical role for FBXW8 and MAPK in cyclin D1 degradation and cancer cell proliferation. PLoS One. 2006;1:e128.

21. Thoms HC, Dunlop MG, Stark LA. p38-mediated inactivation of cyclin D1/ cyclin-dependent kinase 4 stimulates nucleolar translocation of RelA and apoptosis in colorectal cancer cells. Cancer Res. 2007;67(4):1660-9.

22. Shtutman M, Zhurinsky J, Simcha I, Albanese C, D'Amico M, Pestell R, Ben-Ze'ev A. The cyclin D1 gene is a target of the $\beta$-catenin/LEF-1 pathway. Proc Natl Acad Sci U S A. 1999:96(10):5522-7.

23. Giardina C, Inan MS. Nonsteroidal anti-inflammatory drugs, short-chain fatty acids, and reactive oxygen metabolism in human colorectal cancer cells. Biochim Biophys Acta. 1998;1401(3):277-88.

24. Minami T, Adachi M, Kawamura R, Zhang Y, Shinomura Y, Imai K. Sulindac enhances the proteasome inhibitor bortezomib-mediated oxidative stress and anticancer activity. Clin Cancer Res. 2005;11(14):5248-56.

25. Valko M, Rhodes CJ, Moncol J, Izakovic M, Mazur M. Free radicals, metals and antioxidants in oxidative stress-induced cancer. Chem Biol Interact. 2006;160(1):1-40.

26. Trachootham D, Alexandre J, Huang P. Targeting cancer cells by ROS-mediated mechanisms: a radical therapeutic approach? Nat Rev Drug Discov. 2009;8(7): 579-91.

27. Jeong JB, Choi J, Baek SJ, Lee SH. Reactive oxygen species mediate tolfenamic acid-induced apoptosis in human colorectal cancer cells. Arch Biochem Biophys. 2013;537(2):168-75.

28. Schreck R, Rieber P, Baeuerle PA. Reactive oxygen intermediates as apparently widely used messengers in the activation of the NF-KB transcription factor and HIV-1. EMBO J. 1991;10:2247-58.

29. Janssens S, Tschopp J. Signals from within: the DNA-damage-induced NFkappaB response. Cell Death Differ. 2006;13:773-84.

30. Pahl HL. Activators and target genes of Rel/NF-kappaB transcription factors. Oncogene. 1999;18(49):6853-66.

31. Feitelson MA, Arzumanyan A, Kulathinal RJ, Blain SW, Holcombe RF, Mahajna J, Marino M, Martinez-Chantar ML, Nawroth R, Sanchez-Garcia I, 
Sharma D, Saxena NK, Singh N, Vlachostergios PJ, Guo S, Honoki K, Fujii H, Georgakilas AG, Bilsland A, Amedei A, Niccolai E, Amin A, Ashraf SS, Boosani CS, Guha G, Ciriolo MR, Aquilano K, Chen S, Mohammed SI, Azmi AS, Bhakta D, Halicka D, Keith WN, Nowsheen S. Sustained proliferation in cancer: mechanisms and novel therapeutic targets. Semin Cancer Biol. 2015;35:525-54.

32. Malumbres M, Barbacid M. Cell cycle, CDKs and cancer: a changing paradigm. Nat Rev Cancer. 2009;9(3):153-66.

33. Li Y, Wei J, Xu C, Zhao Z, You T. Prognostic significance of cyclin D1 expression in colorectal cancer: a meta-analysis of observational studies. PLoS One. 2014;9(4):e94508.

34. Gillett C, Fantl V, Smith R, Fisher C, Bartek J, Dickson C, Barnes D, Peters G Amplification and overexpression of cyclin D1 in breast cancer detected by immunohistochemical staining. Cancer Res. 1994;54(7):1812-7.

35. Russell A, Thompson MA, Hendley J, Trute L, Armes J, Germain D. Cyclin D1 and D3 associate with the SCF complex and are coordinately elevated in breast cancer. Oncogene. 1999;18(11):1983-91.

36. D'Amico M, Hulit J, Amanatullah DF, Zafonte BT, Albanese C, Bouzahzah B, Fu M, Augenlicht LH, Donehower LA, Takemaru K, Moon RT, Davis R, Lisanti MP, Shtutman M, Zhurinsky J, Ben-Ze'ev A, Troussard AA, Dedhar S, Pestell. $R G$. The integrin-linked kinase regulates the cyclin D1 gene through glycogen synthase kinase 3beta and CAMP-responsive element-binding protein-dependent pathways. J Biol Chem. 2000;275(42):32649-57.

37. Benzeno S, Lu F, Guo M, Barbash O, Zhang F, Herman JG, Klein PS, Rustgi A, Diehl JA. Identification of mutations that disrupt phosphorylation-dependent nuclear export of cyclin D1. Oncogene. 2006;25(47):6291-303.

38. Diehl JA, Zindy F, Sherr CJ. Inhibition of cyclin D1 phosphorylation on threonine-286 prevents its rapid degradation via the ubiquitin-proteasome pathway. Genes Dev. 1997;11(8):957-72.

39. Brown JM, Attardi LD. The role of apoptosis in cancer development and treatment response. Nat Rev Cancer. 2005;5(3):231-7.

40. Wong RS. Apoptosis in cancer: from pathogenesis to treatment. J Exp Clin Cancer Res. 2011;30:87.

41. Liou GY, Storz P. Reactive oxygen species in cancer. Free Radic Res. 2010;44: 479-96.

\section{Submit your next manuscript to BioMed Central and we will help you at every step:}

- We accept pre-submission inquiries

- Our selector tool helps you to find the most relevant journal

- We provide round the clock customer support

- Convenient online submission

- Thorough peer review

- Inclusion in PubMed and all major indexing services

- Maximum visibility for your research

Submit your manuscript at www.biomedcentral.com/submit

) Biomed Central 